\title{
FRASES SEM TEXTO NA PUBLICIDADE DE UMA ESCOLA DE IDIOMAS: DISCURSOS EM TORNO DE UM BRASIL BILÍNGUE
}

\author{
Edgar Godoi GABRIEL (PUC-SP)
}

Poucos ousariam contestar a importância da Língua Inglesa no mundo globalizado em que vivemos. No Brasil, saber inglês é uma necessidade para quem está entrando no mercado de trabalho ou deseja progredir na carreira. Por meio da publicidade, escolas de idiomas têm buscado persuadir a sociedade da importância de seus serviços para a inserção do país no mundo globalizado. Nesse contexto, sobressaem-se duas empresas: Wizard, a maior escola de idiomas do mundo, que, em 2013, foi adquirida pela Pearson, líder mundial em negócios em educação. Juntas, lançaram em 2014 Nação Bilíngue, uma campanha publicitária da Wizard cuja missão é "transformar o Brasil em uma nação bilíngue". Em geral, a publicidade é um frequente objeto de estudo, no entanto, ainda são incipientes as pesquisas que analisam a circulação das chamadas "frases sem texto"na publicidade de escolas de idiomas. Daí a importância deste trabalho, cujo objetivo é analisar, do ponto de vista verbo-visual, os discursos veiculados na campanha publicitária Nação Bilíngue (2014-2017), mais especificamente, depreender os efeitos de sentido produzidos nas/pelas frases sem texto que circulam nos cartazes digitais da referida campanha. Coletados das mídias digitais da Wizard, o corpus é constituído por sete cartazes, referentes às três fases iniciais da campanha: Manifesto, Entrega Resultados e Hino. As análises fundamentam-se nas noções de Frases sem texto, Hiperenunciador e Ethos Discursivo, como preconizadas e desenvolvidas por Dominique Maingueneau. Os resultados mostram que os discursos que circulam na campanha publicitária Nação Bilíngue produzem o efeito de sentido segundo o qual a língua inglesa é tanto uma forma de inserção no mundo globalizado quanto um meio de ascensão social. Indicam ainda que, diferentemente dos slogans publicitários convencionais, os de Nação Bilíngue revelam seu caráter mimotópico, isto é, sua capacidade de adaptar-se a ou metamorfosear-se em outros discursos, simulando até mesmo ser uma não publicidade.

Palavras-chave: Discurso publicitário. Frases sem texto. Mimotopia. 